\title{
Seed predation of Virola bicuhyba (Schott) Warb. (Myristicaceae) in the Atlantic forest of south-eastern Brazil
}

\author{
VALESCA B. ZIPPARRO ${ }^{1}$ and L. PATRÍCIA C. MORELLATO ${ }^{1,2}$
}

(received: December 11, 2003; accepted: May 12, 2005)

\begin{abstract}
Seed predation of Virola bicuhyba (Schott) Warb. (Myristicaceae) in the Atlantic Forest of Southeastern Brazil). Seed predation of Virola bicuhyba (Myristicaceae) was studied in an area of Atlantic forest in south-eastern Brazil, with the objective of testing the Janzen-Connell model. The predation of seeds was evaluated at three different distances from the parent tree for two classes of predators: invertebrates and vertebrates. The method of exclosure plots (closed plots) and open control plots was used, distributed at 5, 15 and $25 \mathrm{~m}$ from the trunk of each adult fruiting tree of $V$. bicuhyba. In Experiment 1, 1,200 seeds were used and, in Experiment 2, 1,440 seeds. Both experiments did not agree with Janzen-Connell model, as seed predation by invertebrates and vertebrates was independent of the distance from the parent tree. Seed predation rate was high, however the impact of predation by vertebrates was higher than by invertebrates, indicating that it is the main cause of seed mortality.
\end{abstract}

Key words - Atlantic forest, exclusion experiment, Janzen-Connell model, seed predation, Virola bicuhyba

RESUMO - (Predação de sementes de Virola bicuhyba (Schott) Warb. (Myristicaceae) em floresta atlântica no sudeste do Brasil). Foi estudada a predação de sementes em Virola bicuhyba (Myristicaceae) em área de floresta atlântica no sudeste do Brasil, com objetivo de testar o modelo de Janzen-Connell de que a mortalidade de sementes aumenta próximo a árvore parental. Foi avaliada a predação de sementes em três diferentes distâncias da árvore mãe e para duas classes de predadores: invertebrados e vertebrados. Foram utilizadas parcelas de exclusão para vertebrados e parcelas controle abertas, distribuídas a 5, 15 e 25 m de distância do tronco de indivíduos de $V$. bicuhyba em frutificação. No Experimento 1 foram utilizadas 1.200 sementes e no Experimento 2, 1.440 sementes. Os dois experimentos não corroboraram o modelo de Janzen-Connell, pois a predação de sementes por invertebrados e vertebrados foi independente da distância da árvore parental. Foram verificadas altas taxas de predação de sementes, porém a predação por vertebrados foi maior do que por invertebrados nos dois experimentos, sendo esta a principal causa da mortalidade das sementes.

Palavras-chave - floresta atlântica, modelo de Janzen-Connell, parcelas de exclusão, predação de sementes, Virola bicuhyba

\section{Introduction}

Seeds are an important food source for a variety of animals (insects, rodents and other vertebrates) in tropical forests (Janzen 1971, Schupp 1988a), which makes the seed stage the phase of the plant life cycle most susceptible to mortality (Janzen 1971). Seed and seedling predation is intense in several tree species and many of them lose a substantial proportion of their seed production to predators (Hubbell 1980, Howe et al. 1985, Schupp 1988a, Cintra \& Horna 1997, Peres et al. 1997). Therefore seed predation may have major effects on the reproductive success of individuals, spatial patterns of populations, genetic variability, interspecific

\footnotetext{
1. Universidade Estadual Paulista, Instituto de Biociências, Departamento de Botânica, Grupo de Fenologia de Plantas e Dispersão de Sementes, Caixa Postal 199, 13506-900 Rio Claro, SP, Brasil.

2._Corresponding author: pmorella@rc.unesp.br
}

interactions and ultimately in the diversity of tree communities (Janzen 1970, Connell 1971, Hubbell 1980, Howe 1989).

Janzen (1970) and Connell (1971) independently suggested that seed and seedling predation could contribute to the maintenance of a high diversity of species in tropical forests. They proposed a qualitative model in which most seeds and seedlings under the crown or in the vicinity of the parent tree are killed by host specific predators, herbivores or pathogens, while those occurring far from the parent tree have a higher chance of survival. As a consequence, the area close to the parent tree would be opened to colonization by juveniles of other species, thus preventing dominance by only one species and increasing diversity.

Although some of the studies conducted in tropical forests have indicated density or distance-dependent seed mortality, a great variation has been found in such patterns (see reviews in Clark \& Clark 1984, Connell et al. 1984, Hammond \& Brown 1998 and also Schupp 1988a, Peres et al. 1997). Other studies only partially 
support the Janzen-Connell model. While invertebrate seed predation is concentrated under and in the immediate vicinity of the parent tree (Howe et al. 1985, Ramírez \& Arroyo 1987, Terborgh et al. 1993, Terborgh \& Wright 1994, Cintra 1997a, Pizo 1997, Wright \& Duber 2001), vertebrate seed predation seems independent of seed density and distance from conspecific adults (De Steven \& Putz 1984, Terborgh et al. 1993, Burkey 1994, Terborgh \& Wright 1994, Peres \& Baider 1997, Pizo1997, Wenny 2000). There are several instances in which individuals of all size classes occur clumped around conspecific adults (Hubbell 1979, Hubbell \& Foster 1983), suggesting that seed mortality does not follow the pattern predicted by the Janzen-Connell model (Hubbell 1980, Schupp 1988b, Schupp 1992, Molofsky \& Fisher 1993, Notman et al. 1996, Blate et al. 1998).

Although the literature on seed and seedling predation in the tropics is extensive, few studies have been conducted in South America, and even a smaller number in Brazil (Tabarelli \& Mantovani 1996, Cintra \& Horna 1997, Peres et al. 1997, Peres \& Baider 1997, Pizo 1997, Silva \& Tabarelli 2001, Silvius \& Fragoso 2002, von Allmen et al. 2004).

The goal of this study was to test the Janzen-Connell model for Virola bicuhyba (Myristicaceae), a tree species from the Brazilian Atlantic forest, addressing the following questions: (1) is seed mortality influenced by the proximity to the parent tree?; (2) which type of seed predators (invertebrates or vertebrates) cause the largest seed mortality? and (3) does the seed predation rate change with time after dispersal?

\section{Material and methods}

Study site and studied species - The present study was carried out at Parque Estadual Intervales (PEI) - Saibadela Research Station, municipality of Sete Barras $\left(24^{\circ} 14^{\prime} 08^{\prime \prime} \mathrm{S}\right.$ and 48 04'42" W), State of São Paulo, South-East Brazil (see Morellato et al. 2000). PEI is a 49,000 ha reserve covered almost completely by pristine Atlantic forest. The altitude at the Saibadela Research Station ranges from 60 to $350 \mathrm{~m}$ a.s.l. The Saibadela region is one of the best preserved areas in the PEI, with a high diversity of frugivores (Aleixo \& Galetti 1997, Monteiro \& Izar 1999). Annual rainfall is around $4,200 \mathrm{~mm}$, with a wetter and hotter season from September to March and a colder and less pronounced rainy season from April to August (for details see Morellato et al. 2000).

Virola bicuhyba (Schott) Warb. (Myristicaceae) is a dioecious canopy tree, 15-30 m in height, frequently occurring in dense primary Atlantic rain forest (Rodrigues 1980). At the study site Guilherme et al. (2004) surveyed 24 adult trees (> $5 \mathrm{~cm} \mathrm{dbh}$ ) per $1.98 \mathrm{ha}$. The studied species is widely distributed in the tropical forests from Central America (Guatemala) to southern Brazil, and from the western coast of Colombia to the Brazilian Atlantic Coast (Rodrigues 1980). The fruit is a dehiscent capsule ca. $3.5 \mathrm{~cm}$ long and $2.5 \mathrm{~cm}$ wide, which opens to expose a lipid-rich red aril, covering the entire seed (Rodrigues 1980). The brown seed is $2.14( \pm 0.21)$ cm long and $1.50( \pm 0.1) \mathrm{cm}$ wide, and $2.85( \pm 0.56) \mathrm{g}$ mean weight ( $\mathrm{n}=494$ seeds). At the studied site $V$. bicuhyba fruits from June to September (Morellato et al. 2000). The fruits (aril) are eaten by a variety of frugivores, especially large birds such as toucans and bellbirds (Galetti et al. 2000).

Methods - Five fruiting trees of V. bicuhyba at least $100 \mathrm{~m}$ apart from each other and $50 \mathrm{~m}$ from any conspecific fruiting tree were selected for the experiments, described below.

Experiment 1 - Initiated in September of 1995 at the end of the fruiting season of $V$. bicuhyba: Under each fruiting tree 240 plots $(0.20 \times 0.20 \mathrm{~m})$ were established to separate vertebrate from invertebrate seed predation; vertebrate exclosure plots (closed plots) were made of wire netting (mesh of $1.27 \mathrm{~cm}$ ) to permit the entrance of invertebrates only. Open plots allowed both vertebrates and invertebrates to access the seed. Both kinds of plots were delimited by four aluminium stakes. Four types of treatment were considered: closed plots with arillate seeds, closed plots with aril removed seeds, open plots with arillate seeds and opened plots with non-arillate seeds. The four treatments were distributed around three concentric circles at $5 \mathrm{~m}$ (under the crown), $15 \mathrm{~m}$ (edges of the crown) and $25 \mathrm{~m}$ (far from the crown) from the trunk of the adult tree. Sixteen plots, four repetitions for each treatment, were placed in each circle, totalling 48 plots per tree. Five V. bicuhyba seeds were set out in each plot, totalling 240 seeds per tree (120 arillate and 120 non-arillate), and 1,200 seeds for all five trees combined. The leaf litter was removed from the plots to facilitate the location of seeds. The sequence of plots in the circles was randomly distributed. The distances between plots were $1.9,5.8$, and $9.8 \mathrm{~m}$ from the inner to the outer circles, respectively, with a high seed density in the inner circle thus simulating natural seed fall.

Arillate and non-arillate seeds were collected under or directly from the crown of non-experimental trees. Seeds with abnormal shapes or signs of predation were discarded. Seeds were kept in the refrigerator (about $10^{\circ} \mathrm{C}$ ) until the total number of seeds was obtained. The storage period lasted from July to September of 1995.

It was not possible to compare the removal and predation rates between arillate and non-arillate seeds due to the fast removal of the aril by invertebrates such as harvestmen, grasshoppers and especially ants. The ants removed the aril, cleaning the seeds in less than $15 \mathrm{~h}$ (Pizo \& Oliveira 2001). The aril-treatments were disregarded and the data were considered as two treatments only: open and closed plots with non-arillate seeds, and eight repetitions by circle.

The plots were observed monthly from October 1995 to July 1996. Seeds were classified in three categories: intact seeds (seeds without apparent signs of predation), damaged 
seeds (seeds attacked by invertebrates) and removed seeds (seeds disappeared or not found in an area around $50 \mathrm{~cm}$ of the plot). A seed removed by vertebrate or attacked by invertebrate was considered to be equivalent to seed predation (Terborgh et al. 1993, Terborgh \& Wright 1994).

A Kolmogorov-Smirnov test (Zar 1996) was used to test the data distribution. Repeated-measures analysis of variance was used to test for differences in predation rates among the three distances (Zar 1996). Two factors were considered the distance (three measurements) and time (number of months observed). The data used in the analysis is cumulative - the number of predated seeds in the first month was added to the number of predated seeds in the second month and so on. The $\chi^{2}$ test was applied to verify if there was significant difference between the total number of seeds removed by vertebrates and the total number of seeds predated by invertebrates.

Experiment 2 - The exclusion experiment was repeated during the fruiting season of the following year (1996): Some alterations in the experimental design were made to improve Experiment 1. Due to the fast removal of the aril observed in Experiment 1, only two treatments were used in Experiment 2: closed and open plots, both with seeds without arils. In the closed plots the wire mesh was fixed with a larger number of staples to avoid the eventual entrance of small rodents as verified in Experiment 1.

Six repetitions for each treatment type (12 plots) were used for each circle, in the same intervals, totaling 36 plots per tree and 180 plots for all five trees. Eight seeds were placed in each plot, totalling 96 seeds per circle, 288 seeds per tree and 1,440 seeds for all five trees combined. The distances among plots were of 2.5, 7.6 and $12.8 \mathrm{~m}$ from the inner to the outer circles, respectively. The six closed and six open plots were alternate along each circle.

Seeds were also collected on the ground under other trees of $V$. bicuhyba and as soon as sufficient seeds for one tree were obtained, the experiment was set up. This procedure avoided long periods of seed storage in the refrigerator, which could affect seed germination, as observed in Experiment 1. The observations were made monthly from September 1996 to March 1997. The seeds were classified as in Experiment 1: intact, attacked and removed.

\section{Results}

For both experiments, high rates of seed predation by invertebrates and vertebrates were recorded independently of the distance from the parent tree. The repeated-measures ANOVA showed non-significant differences for invertebrate predation at the three distances; however, time significantly affected seed predation by invertebrates (table 1). There was no significant interaction between distance and time (table 1).

The percentage of seeds attacked by invertebrates in the closed plots was higher in the first four months, decreasing in the last months (figure $1 \mathrm{~A}, \mathrm{~B}$ ). The distances where predation was more intense changed over the months.

Due to the intense and fast rate of seed removal by vertebrates from open plots, few seeds remained to be attacked by invertebrates. During Experiment 1, in the first month of observation, only one seed was attacked by insects at the distance of $5 \mathrm{~m}(0.5 \%)$ (figure 1A), but this seed disappeared in the next month. In Experiment 2 there were seeds predated by insects only in the first three months of observation (rates ranging from $0.42-2 \%$ ) (figure $1 \mathrm{~B}$ ).

In both experiments, the rates of seed removal by vertebrates from open plots were intense, fast and similar for the three distances (figure 2A, B). In Experiment 1, in the first month (October 1995) the removal rates were $96.5 \%$ for $5 \mathrm{~m}$ and $100 \%$ for 15 and $25 \mathrm{~m}$; in November 1995 the remaining seeds were removed $(3.5 \%)$ (figure 2A). In Experiment 2, the removal was slightly lower than that observed in the previous year (figure 2B); in the first month of observation the removal rates were $88.3 \%, 94.5 \%$ and $91.2 \%$ for 5,15 and $25 \mathrm{~m}$, respectively (figure $2 \mathrm{~B}$ ). In the second month the rates were $7.5 \%, 3.7 \%$ and $7.9 \%$ for 5,15 and $25 \mathrm{~m}$, respectively, and in the third month all the remaining seeds were removed. Occasionally, in both years seed

Table 1. Summary of repeated measures analysis of variance (ANOVA) for insect seed predation of Virola bicuhyba at three different distances from parent tree, during Experiment 1 (1995/1996) and Experiment 2 (1996/1997). DF = Degrees of freedom; $\mathrm{F}=\mathrm{F}$ test $\mathrm{P}=$ Probability.

\begin{tabular}{lcccccc}
\hline & \multicolumn{3}{c}{ Experiment 1 } & \multicolumn{3}{c}{ Experiment 2 } \\
\cline { 2 - 7 } Sources of variation & DF & F & P & DF & F & P \\
\hline Distance & 2 & 3.329 & 0.089 & 2 & 0.610 & 0.567 \\
Time & 9 & 25.732 & $<0.0001$ & 6 & 85.736 & $<0.0001$ \\
Distance $\times$ Time & 18 & 0.534 & 0.932 & 12 & 0.498 & 0.498 \\
\hline
\end{tabular}


fragments were found inside the plots, suggesting that removal was in fact due to predation. Low rates of seed removal were observed in closed plots (figure 2A, B). The removal was probably caused by small rodents, that can pass underneath the wire mesh, digging a small tunnel to enter into the plot (V.B. Zipparro, unpublished data). Field observations and the tunnel dimension indicate the rodent Oligoryzomys spp. (E.M. Vieira, pers. com.) as the most likely responsible for that removal. The seed removal from the closed plots during Experiment 2 was smaller than in Experiment 1, with rates ranging from $0.4 \%$ to $2.5 \%$ (figure $2 \mathrm{~B}$ ). The removal of $V$. bicuhyba seeds from closed plots occurred even when seeds had been already attacked by insects.

Seed predation by vertebrates was significantly greater than by invertebrates in both experiments $\left(\chi^{2}=56.7, \mathrm{P}<0.05\right.$ and $\left.\chi^{2}=10.6, \mathrm{P}<0.05\right)$ (table 2). In Experiment 1 the rate of seed predation caused by vertebrates reached up to $60.5 \%$ (including closed plots), while insects were responsible for $38.8 \%$ of the total seed predation (table 2$)$. The few seeds left $(0.7 \%)$ died due to pathogens, desiccation, etc. In Experiment 2 vertebrates removed $51.5 \%$ of the seeds (including the
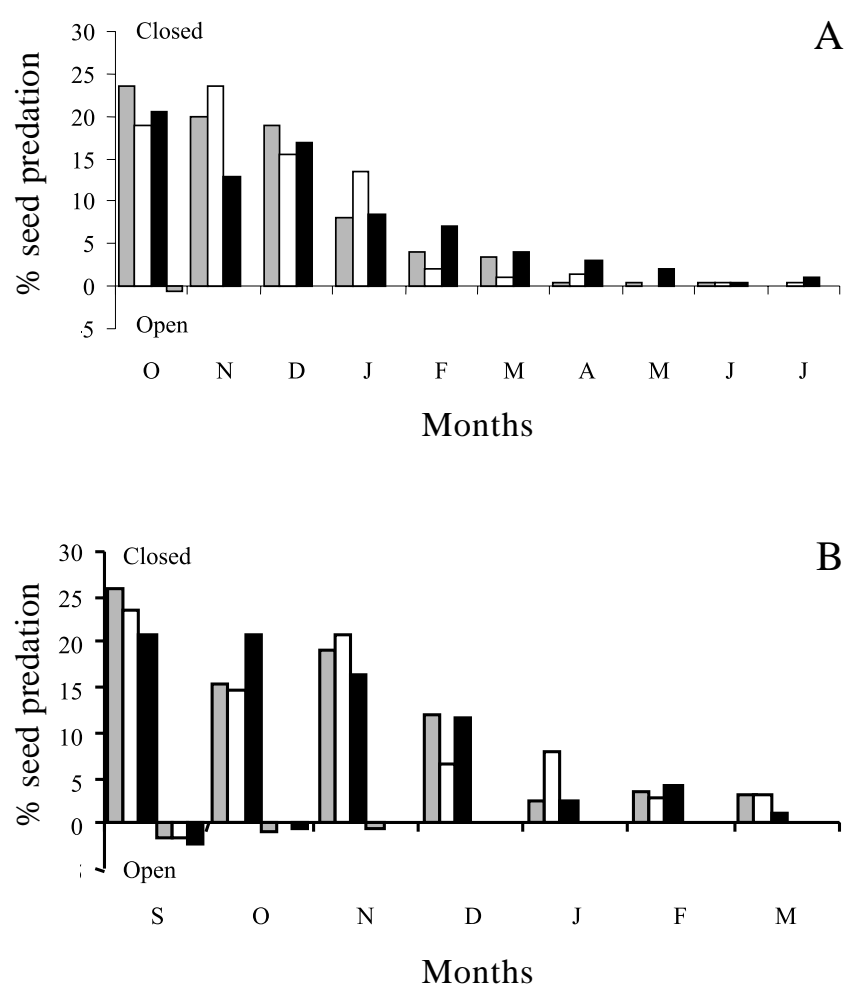

Figure 1. Percentage of Virola bicuhyba (Myristicaceae) seeds preyed upon by insects in the closed plots (superior axis) and open plots (inferior axis) during Experiment 1 (A), and Experiment 2 (B), in a Brazilian Atlantic Rainforest. $\square=5 \mathrm{~m} ; \square=15 \mathrm{~m} ; \boldsymbol{\square}=25 \mathrm{~m}$. seeds removed from closed plots), while the insects caused $43.3 \%$ of the seed predation (table 2).

No seedling development was observed from seeds used in Experiment 1. Storage in the refrigerator prior to the test may have affected the germination capacity of the seeds. In Experiment 2 the rate of seedling appearance was $2.6 \%$ (closed plots) and $0.07 \%$ (open plots), while the remaining seeds $(2.53 \%)$ died due to other causes. The germinated seeds in the Experiment 2 were preyed upon by Stelidota geminata (Nitidulidae) or other organisms, or died due to other causes (fungi and other pathogens, dehydration, etc.). Thirty-six seedlings developed in closed plots, though by the end of the observation period three of them had died due to unknown causes. Due to the high seed removal in opened plots, only one seedling was obtained at the distance of $25 \mathrm{~m}$.

Seed predators - During the two observation periods only one species of insect was observed inside the seeds of $V$. bicuhyba: the strawberry sap beetle Stelidota geminata Say (Coleoptera, Nitidulidae). Stelidota geminata is a small oval-shaped beetle 3-4 mm long $(\mathrm{n}=15$ individuals), with a wide geographical distribution
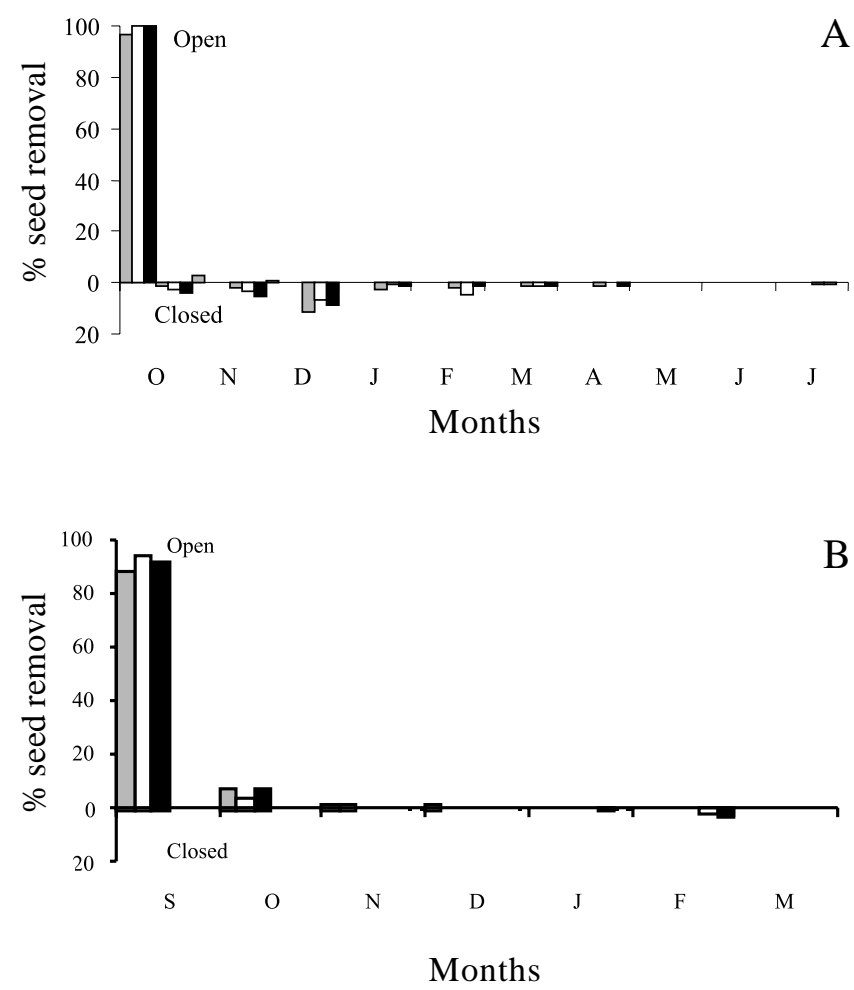

Figure 2. Percentage of Virola bicuhyba (Myristicaceae) seeds preyed upon by vertebrates in the open plots (superior axis) and closed plots (inferior axis) during Experiment 1 (A), and Experiment 2 (B), in a Brazilian Atlantic Rainforest. $=5 \mathrm{~m} ; \square=15 \mathrm{~m} ; \boldsymbol{\square}=25 \mathrm{~m}$. 
Table 2. Total number of Virola bicuhyba seeds preyed upon by invertebrates and vertebrates (including in the closed plots), during Experiment 1 (1995/1996) and Experiment 2 (1996/1997) and number of seedlings in the Experiment 2.

\begin{tabular}{|c|c|c|c|c|c|c|}
\hline \multirow[b]{3}{*}{ Month } & \multicolumn{6}{|c|}{ Number of predated seeds } \\
\hline & \multicolumn{2}{|c|}{ Experiment 1} & \multicolumn{4}{|c|}{ Experiment 2} \\
\hline & $\begin{array}{l}\text { Invertebrates } \\
\quad(\mathrm{n}=600)\end{array}$ & $\begin{array}{c}\text { Vertebrates } \\
(\mathrm{n}=600)\end{array}$ & $\begin{array}{l}\text { Invertebrates } \\
\quad(\mathrm{n}=720)\end{array}$ & $\begin{array}{l}\text { Vertebrates } \\
(\mathrm{n}=720)\end{array}$ & $\begin{array}{c}\text { Seedlings } \\
\text { (closed plots) }\end{array}$ & $\begin{array}{c}\text { Seedlings } \\
\text { (open plots) }\end{array}$ \\
\hline September & - & - & 181 & 659 & 0 & 0 \\
\hline October & 126 & 608 & 122 & 46 & 0 & 0 \\
\hline November & 113 & 26 & 138 & 11 & 3 & 0 \\
\hline December & 103 & 53 & 94 & 6 & 22 & 0 \\
\hline January & 60 & 9 & 39 & 6 & 7 & 1 \\
\hline February & 26 & 15 & 28 & 13 & 2 & 0 \\
\hline March & 17 & 8 & 21 & 1 & 2 & 0 \\
\hline April & 10 & 5 & - & - & & \\
\hline May & 5 & 0 & - & - & & \\
\hline June & 3 & 0 & - & - & & \\
\hline July & 3 & 2 & - & - & & \\
\hline Total & 466 & $726^{*}$ & 623 & $742 *$ & 36 & 1 \\
\hline
\end{tabular}

* including the seeds removed from closed plots

(Blackmer \& Phelan 1992). Stelidota geminata apparently completes several life cycles in the seeds. In every month it was possible to observe larvae and adults feeding on the seeds until their almost complete consumption.

Seed removal from open plots during Experiments 1 and 2 may be attributed to rodents captured near to the experimental trees. In captivity, the species of small rodents such as Olygorizomys spp., just fed on the aril, and the medium to big rodents such as Oryzomys intermedius, Oecomys gr. concolor, Nectomys squamipes and Proechimys iheringii (Rodentia) consumed the seed (E. M. Vieira, unpubl. data).

\section{Discussion}

The results for seed predation by vertebrates did not support the Janzen-Connell model, because there were no significant differences in seed predation between the three analyzed distances, in the two years of observation. The high availability of seeds of Virola bicuhyba during the fruiting period, associated to the overall constant fruit production over the year at the Saibadela forest (Morellato et al. 2000), may produce a high density seed shadow. As many rodents are density responsive, in a high density scenario rodents can find seeds everywhere and little spatial variation on seed removal is expected. In fact, von Allmen et al. (2004) studying seed predation of Euterpe edulis Mart. at the same site, suggest that, under high seed density conditions, escaping of seed predation is more a question of when seed is dispersed than of where it is deposited. Other studies accomplished in tropical forests, besides Brazil, also did not corroborate the Janzen-Connell model for predation by vertebrates: Terborgh et al. (1993), Burkey (1994), Terborgh \& Wright (1994), Peres \& Baider (1997), Pizo (1997), Wenny (2000). Terborgh et al. (1993), Terborgh \& Wright (1994), and Wright (2002) have suggested that mammals have a larger life area than insects, are polyphagous and forage for seeds in great extensions, causing a more uniform impact on the seeds present on the forest ground, independent of the density and of the distance from the parent tree.

The removal of the leaf litter may have facilitated the location of seeds by predators and contributed to their fast removal. Cintra (1997b) and Cintra \& Terborgh (2000) demonstrated that the survival of big seeds is greater in micro sites covered by leaf litter.

The fragments of seeds found inside the plots suggest that seed removal is equivalent to seed predation. Schupp \& Frost (1989) argued that even if some removed seeds survive, the removal tends to correlate strongly with predation. These and other authors also found signs of seeds consumed inside experimental plots (Schupp \& Frost 1989), plastic trays (Díaz et al. 1999) or tied to nylon threads (Burkey 1994, Blate et al. 1998). On the other hand, few studies 
observed dispersion of seeds after their removal (Forget 1992a, Asquith et al. 1997).

Seed removal observed in the closed plots during the two observation periods was considered low (rates between $0.5 \%$ and $11 \%$ ), which is similar to the results obtained by Terborgh et al. (1993), Terborgh \& Wright (1994), Asquith et al. (1997) and Notman \& Gorchov (2001).

Seed removal by vertebrates was significantly larger than seed predation by invertebrates in the two experiments and was, therefore, considered the main cause of seed mortality in $V$. bicuhyba in the studied area. Terrestrial mammals, particularly rodents, are indicated as being the main predators of seeds in most of the studies carried out in tropical forests (SánchezCordero \& Martínez-Gallardo 1998, Notman \& Gorchov 2001). The seeds protected by wire screens presented larger survival rates than unprotected seeds, suggesting that the removal by vertebrates limited the formation of seedlings in $V$. bicuhyba. De Steven \& Putz (1984) and Asquith et al. (1997) found that seeds of Dipteryx panamensis (Pittier) Record \& Mell, Gustavia superba O. Berg. and Virola nobilis A.C. Sm. protected from mammals present high rates of germination and establishment success in the Barro Colorado Island and on the Gigante Peninsula, Panama. Sork (1987) and Schupp (1990) demonstrated that predation of seeds reduced the appearance of seedlings and consequently the recruitment of Astrocaryum mexicanum Liebm. ex Mart. and Gustavia superba. Notman \& Gorchov (2001) found that the predation by vertebrates was the main cause of large seed mortality for 26 species of trees and lianas, in a study accomplished in a lowland tropical forest in Peru.

Even though the impact caused on the seeds of $V$. bicuhyba by insects was significantly lower than vertebrates, the rates obtained for insect predation can be considered as high. Seed predation caused by Stelidota geminata during the two experiments did not also corroborate the Janzen-Connell model, because there were no significant differences between the numbers of seeds preyed upon at the three different distances. This pattern, as discussed before, could be related to the high density of seeds available on the forest floor to $S$. geminata, a generalist coleoptera, with about 14 species of related host fruits (Blackmer \& Phelan 1992). A phenological study accomplished in the same area and period of observation as the present study showed that fruits are available throughout the whole year (Morellato et al. 2000), which suggests that these generalist coleoptera may be distributed over the forest floor throughout the year. von Allmen et al. (2004) have found no effect of distance on palm heart seed predation under high seed density. Notman et al. (1996) argued that seed predation of Macoubea guianensis Aubl. by ants occurred independently to the density and distance, because the colonies of ants were dispersed over the whole forest floor. On the other hand, most of the studies accomplished in tropical forests, besides Brazil, have supported the Janzen-Connell model for the predation by invertebrates: Howe et al. (1985), Ramírez \& Arroyo (1987), Terborgh et al. (1993), Terborgh \& Wright (1994), Cintra (1997a), Pizo (1997), Wenny (2000), Wright \& Duber (2001).

The recruitment of Virola bicuhyba in the seed stage was very low in the study area, during the two years of observation, as a consequence of the intense predation by insects and vertebrates. The present study demonstrates that the Janzen-Connell model cannot be applied for Virola bicuhyba in the studied Atlantic forest, because the predation of seeds occurred independently to the density of seeds and to the distance from the parent plant, confirming the pattern observed in areas under a high seed density (Condit et al. 2000, von Allmen et al. 2004). Studies accomplished with other species of Myristicaceae and different species of Virola have partly supported (Howe et al. 1985) or did not corroborated (Molofsky \& Fisher 1993, Asquith et al. 1997, Blate et al. 1998) the Janzen-Connell model, suggesting that other factors can influence seed predation in tropical forests. Safe sites for the establishment of healthy seedlings are relatively rare and unpredictable in time and space (Wheelwright \& Orians 1982, Janzen 1983, Whelan et al. 1991). Moreover, there is a long-term need for more studies that take into account the influence of many factors, besides distance and density, in the predation and recruitment of seeds in tropical forest species.

Acknowledgments - We are grateful to the Fundação Florestal and Instituto Florestal do Estado de São Paulo for permission to work at Parque Estadual Intervales, and for providing logistic support. We also thank L. Dias, P. Izar and M. Galetti for helping in many ways during the field work, and P. Feisinger for advice the statistical analysis. S.A. Vanin, E.M. Vieira and W.A. Rodrigues for identifications. The manuscript was improved with criticisms by M.A. Pizo and two anonymous reviewrs, and with the English review by A. d'Heursel. This research was supported by a grant from Fundação de Amparo à Pesquisa do Estado de São Paulo (FAPESP, \#95/09626-0) to L.P.C.M. Capes provided a master fellowship to V.B.Z., and L.P.C.M. receives a research productivity fellowship from the Brazilian Research Council (CNPq). 


\section{References}

ALEIXO, A. \& GALETTI, M. 1997. The conservation of the avifauna in a lowland Atlantic Forest in south-east Brazil. Bird Conservation International 7:235-261.

ASQUITH, N.M., WRIGHT, S.J. \& CLAUSS, M.J. 1997. Does mammal community composition control recruitment in neotropical forests? Evidence from Panama. Ecology 78:941-946.

BLACKMER, J.L. \& PHELAN, L.P. 1992. Chemical "generalists" and behavioral "specialists": a comparison of host finding by Stelidota geminata and Stelidota octomaculata. Entomologia Experimentalis et Applicata 63:249-257.

BLATE, G.M., DAVID, R.P. \& LEIGHTON, M. 1998. Post dispersal predation on isolated seeds: a comparative study of 40 tree species in a southeast Asian rainforest. Oikos 82:522-538.

BURKEY, T.V. 1994. Tropical tree species diversity: a test of the Janzen-Connell model. Oecologia 97:533-540.

CINTRA, R. 1997a. A test of the Janzen-Connell model with two common tree species in Amazonian forest. Journal of Tropical Ecology 13:641-658.

CINTRA, R. 1997b. Leaf litter effects on seed and seedling predation of the palm Astrocaryum murumuru and the legume Dipteryx micrantha in Amazonian forest. Journal of Tropical Ecology 13:709-725.

CINTRA, R. \& HORNA, V. 1997. Seed and seedling survival of the palm Astrocaryum murumuru and the legume tree Dipteryx micrantha in gaps in Amazonian forest. Journal of Tropical Ecology 13:257-277.

CINTRA, R. \& TERBORGH, J. 2000. Forest microspatial heterogeneity and seed and seedling survival of the palm Astrocaryum murumuru and the legume Dipteryx micrantha in an Amazonian forest. Ecotropica 6:77-88.

CLARK, D.A. \& CLARK, D.B. 1984. Spacing dynamics of a tropical rain forest tree; evaluation of the Janzen-Connell model. American Naturalist 124:769-788.

CONDIT, R., ASHTON, P.S., BAKER, P., BUNYAVEJCHEWIN, S., GUNATILLEKE, S., GUNATILLEKE, N., HUBBELL, S.P., FOSTER, R.B., HUA SENG, L., ITOH, A., LAFRANKIE, J.V., LOSOS, E., MANOKARAN, N., SUKUMAR, R. \& YAMAKURA, T. 2000. Spatial patterns in the distribution of common and rare tropical tree species: a test from large plots in six different forests. Science 288:1414-1418.

CONNELL, J.H. 1971. On the role of natural enemies in preventing competitive exclusion in some marine animal and in rain forest trees. In Dynamics of populations (P.J. Den Boen \& P.R. Gradwell, eds.). Pudoc, Wageningen, p. 298-312.

CONNELL, J.H., TRACEY, J.G. \& WEBB, L.J. 1984. Compensatory recruitment, growth, and mortality as factors maintaining rain forest tree diversity. Ecological Monographs 54:141-164.
DE STEVEN, D. \& PUTZ, F.E. 1984. Impact of mammals on early recruitment of a tropical canopy tree, Dipteryx panamensis, in Panama. Oikos 43:207-216.

DÍAZ, I., PAPIC, C. \& ARMESTO, J.J. 1999. An assessment of post-dispersal seed predation in temperate rain forest fragments in Chiloé Island, Chile. Oikos 87:228-238.

FORGET, P.M. 1992a. Seed removal and seed fate in Gustavia superba (Lecythidaceae). Biotropica 24:408-414.

GALETTI, M., LAPS, R. \& PIZO, M.A. 2000. Frugivory by toucans (Ramphastidae) at two altitudes in the Atlantic Forest of Brazil. Biotropica 32:842-850.

GUILHERME, F.A.G., MORELLATO, L.P.C. \& ASSIS, M.A. 2004. Horizontal and vertical tree community structure in a lowland Atlantic Rain Forest, Southeastern Brazil. Revista Brasileira de Botânica 27: 725-737.

HAMMOND, D.S. \& BROWN, V.K. 1998. Disturbance, phenology and life-history characteristics: factors influencing distance/density-dependent attack on tropical seeds and seedlings. In Dynamics of tropical communities (D.M. Newbery, H.H.T. Prins \& N.D. Brown, eds.). Blackwell Scientific, Oxford, p. 51-78.

HOWE, H.F. 1989. Scatter and clump-dispersal and seedling demography: hypothesis and implications. Oecologia 79:417-426.

HOWE, H.F., SCHUPP, E. \& WESTLEY, L.C. 1985. Early consequences of seed dispersal for a neotropical tree (Virola surinamensis). Ecology 66:781-791.

HUBBELL, S.P. 1979. Tree dispersion, abundance and diversity in a tropical dry forest. Science 213:1299-1309.

HUBBELL, S.P. 1980. Seed predation and the coexistence of tree species in tropical forests. Oikos 35: 214-229.

HUBBELL, S.P. \& FOSTER, R. 1983. Diversity of canopy trees in a neotropical forest and implications for conservation. In The tropical rain forest: ecology and management (S.L. Sutton, T.C. Whitmore \& A.C. Chadwick, eds.). Blackwell Science, Oxford, p.25-41.

JANZEN, D.H. 1970. Herbivores and the number of trees species in tropical forests. American Naturalist 104:501-528.

JANZEN, D.H. 1971. Seed predation by animals. Annual Review of Ecology and Systematics 2:465-492.

JANZEN, D.H. 1983. Seed and pollen dispersal by animals: convergence in the ecology of contamination and sloppy harvest. Biological Journal of the Linnean Society 20:103-113.

MOLOFSKY, J. \& FISHER, B.L. 1993. Habitat and predation effects on seedling survival and growth in shade-tolerant tropical trees. Ecology 74:261-265.

MONTEIRO, E.M. \& IZAR, P. 1999. Interactions between aroids and arboreal mammals in the Brazilian Atlantic rainforest. Plant Ecology 145:75-82.

MORELLATO, L.P.C., TALORA, D.C., TAKAHASI, A., BENCKE, C.C., ROMERA, E.C. \&ZIPPARRO, V.B. 2000. Phenology of Atlantic rainforest trees: a comparative study. Biotropica 32:811-823. 
NOTMAN, E. \& GORCHOV, D.L. 2001. Variation in postdispersal seed predation in mature Peruvian lowland tropical forest and fallow agricultural sites. Biotropica 33:621-636.

NOTMAN, E., GORCHOV, D.L. \& CORNEJO, F. 1996. Effect of distance, aggregation, and habitat on levels of seed predation for two mammal-dispersed neotropical rainforest tree species. Oecologia 106:221-227.

PERES, C.A. \& BAIDER, C. 1997. Seed dispersal, spatial distribution and population structure of Brazilnut trees (Bertholletia excelsa) in south-eastern Amazonia. Journal of Tropical Ecology 13:595-616.

PERES, C.A., SCHIESARI, L.C. \& DIAS-LEME, C.L. 1997. Vertebrate predation of brazil - nuts (Bertholletia excelsa, Lecythidaceae), an agouti - dispersed Amazonian seed crop: a test of the escape hypothesis. Journal of Tropical Ecology 13:69-79.

PIZO, M.A. 1997. Seed dispersal and predation in two populations of Cabralea canjerana (Meliaceae) in the Atlantic Forest of south-eastern Brazil. Journal of Tropical Ecology 13:559-578.

PIZO, M.A. \& OLIVEIRA, P.S. 2001. Size and lipid content of nonmyrmecochorous diaspores: effects on the interaction with litter-foraging ants in the Atlantic rain forest of Brazil. Plant Ecology 157:37-52.

RAMÍREZ, N. \& ARROYO, M.K. 1987. Variación espacial y temporal en la depredación de semillas de Copaifera pubiflora Benth. (Leguminosae: Caesalpinioideae) en Venezuela. Biotropica 19:32-39.

RODRIGUES, W.A. 1980. Revisão taxonômica das espécies de Virola Aublet (Myristicaceae) do Brasil. Acta Amazonica (suplemento): 1-127.

SÁNCHEZ-CORDERO, V. \& MARTÍNEZ-GALLARDO, R. 1998. Postdispersal fruit and seed removal by forestdwelling rodents in a lowland rainforest in Mexico. Journal of Tropical Ecology 14:139-151.

SCHUPP, E.W. 1988a. Seed and early seedling predation in the forest understory and in treefall gaps. Oikos 51:71-78.

SCHUPP, E.W. 1988b. Factors affecting post dispersal seed survival in a tropical forest. Oecologia 76:525-530.

SCHUPP, E.W. 1990. Annual variation in seedfall, postdispersal predation, and recruitment of a neotropical tree. Ecology 71:504-515.

SCHUPP, E.W. 1992. The Janzen-Connell model for tropical tree diversity - population implications and the importance of spatial scale. American Naturalist 140:526-530.

SCHUPP, E.W. \& FROST, E.J. 1989. Differential predation of Welfia georgii seeds in treefall gaps and the forest understory. Biotropica 21:200-203.
SILVA, M.G. \& TABARELLI, M. 2001. Seed dispersal, plant recruitment and spatial distribution of Bactris acanthocarpa Martius (Arecaceae) in a remnant of Atlantic forest in northeast Brazil. Acta Oecologica 22:259-268.

SILVIUS, K.M. \& FRAGOSO, J.M.V. 2002. Pulp handling by vertebrate seed dispersers increases palm seed predation by bruchid beetles in the northern Amazon. Journal of Ecology 90:1024-1032.

SORK, V.L. 1987. Effects of predation and light on seedling establishment in Gustavia superba. Ecology 68:1341-1350.

TABARELLI, M. \& MANTOVANI, W. 1996. Remoção de sementes de Bertholletia excelsa (Lecythidaceae) por animais em uma floresta de terra firme na Amazônia Central, Brasil. Revista Brasileira de Biologia 56:755-760.

TERBORGH, J. \& WRIGHT, S.J. 1994. Effects of mammalian herbivores on plant recruitment in two neotropical forests. Ecology 75:1829-1833.

TERBORGH, J.,LOSOS, E., RILEY,M.P. \& BOLAÑOS-RILEY, M. 1993. Predation by vertebrates and invertebrates on the seeds of five canopy tree species of an Amazonian forest. Vegetatio 107/108:375-386.

von ALLMEN, C., MORELLATO, L.P.C. \& PIZO, M.A. 2004. Seed predation under high seed density condition: the palm Euterpe edulis in the Brazilian Atlantic Forest. Journal of Tropical Ecology 20:471-474.

WENNY, D.G. 2000. Seed dispersal, seed predation, and seedling recruitment of a neotropical montane tree. Ecological Monographs 70:331-351.

WHEELWRIGHT, N.T. \& ORIANS, G.H. 1982. Seed dispersal by animals: contrasts with pollen dispersal, problems of terminology, and constraints on coevolution. American Naturalist 119:401-413.

WHELAN C.J., WILLSON, M.F., TUMA, C.A. \& SOUZA PINTO, I. 1991. Spatial and temporal patterns of postdispersal seed predation. Canadian Journal of Botany 69:428-436.

WRIGHT, S.J. 2002. Plant diversity in tropical forests: a review of mechanisms of species coexistence. Oecologia 130:1-14.

WRIGHT, S.J. \& DUBER, H.C. 2001. Poachers and forest fragmentation alter seed dispersal, seed survival, and seedling recruitment in the palm Attalea butyracea, with implications for tropical tree diversity. Biotropica 33:583-595.

ZAR, J.H. 1996. Biostatistical analysis. Prentice-Hall, New Jersey. 